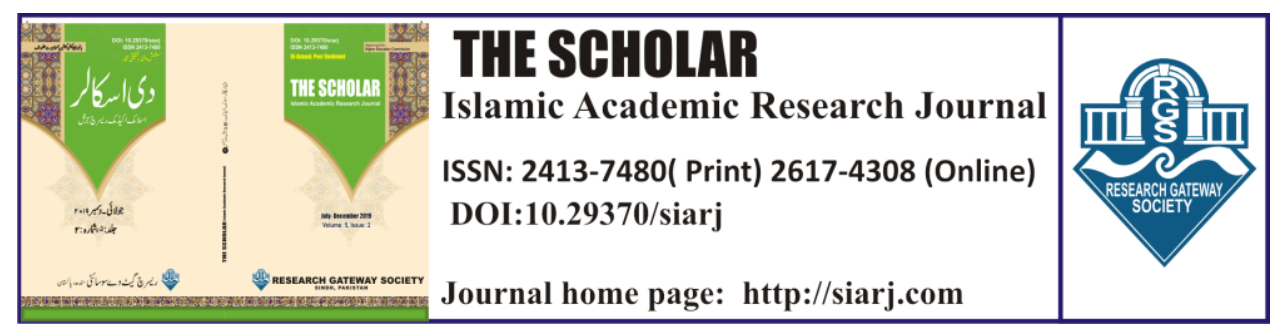

\title{
DEVELOPING AN UNDERSTANDING OF GENDER BASED SOCIAL INTERACTION PRINCIPLES IN ISLAMIC TEACHINGS
}

\section{Masood Ahmad}

Assistant professor, Inte rnational Islamic University, Islamabad, Pakistan

Email: masood.ahmed@iiu.edu.pk

ORCID IID:

https://orcid.org/0000-0002-9804-8314

\section{Zahida Parveen}

Professor, Government Viqar-unNisa Post Graduate College for Women, Rawalpindi, Pakistan

Email: ztvnrwp@gmail.com ORCIID IID:

https://orcid.org/0000-0002-4852-5602

3. Muhammad Anas Muhammad Shoaib

Lecturer, Department of Hadith, International Islamic University, Islamabad, Pakistan

Email: al.jindwi@gmail.com

ORCID IID:

https://orcid.org/0000-0002-1140-1569

To cite this article:

Ahmad, Masood, Zahida Parveen, and Muhammad Anas Muhammad Shoaib. "DEVELOPING AN UNDERSTANDING OF GENDER BASED SOCIAL INTERACTION PRINCIPLES IN ISLAMIC TEACHINGS.” The ScholarIslamic Academic Research Journal 6, no. 1 (May 31, 2020): 189-219. To link to this article: https://doi.org/10.29370/siarj/issue10ar14

\begin{tabular}{|c|c|}
\hline Publisher & $\begin{array}{l}\text { The Scholar Islamic Academic Research Journal } \\
\text { Vol. 6, No. } 1 \text { || January -June } 2020 \text { || P.189-219 } \\
\text { Research Gateway Society }\end{array}$ \\
\hline DOI: & $10.29370 /$ siari/issue10ar14 \\
\hline URL: & https://doi.org/10.29370/siarj/issue10ar14 \\
\hline License: & Copyright c 2017 NC-SA 4.0 \\
\hline Journal homepage & www.siarj.com \\
\hline Published online: & $2020-05-31$ \\
\hline
\end{tabular}
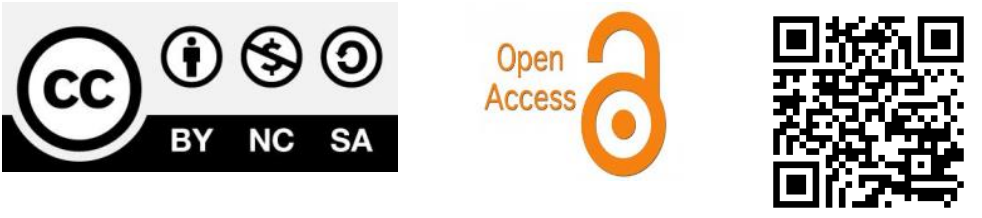
THE SCHOLAR (January- June 2020)

\section{DEVELOPING AN UNDERSTANDING OF GENDER BASED SOCIAL INTERACTION PRINCIPLES IN ISLAMIC TEACHINGS}

Masood Ahmad, Zahida Parveen, Muhammad Anas Muhammad Shoaib

\section{ABSTRACT:}

The main purpose of this study was to explore principles of gender interaction in Islamic teachings. Now-a-days Muslims find themselves asking what the guidelines are for men \& women to interact and socialize with each other if they need to, except such texts do not exist. In-short, the scholars of the past dealt with the academic aspect of gender intermixing, but did not shed light on the practical side of it. Our society cannot flourish without professional and healthy interactions between men and women. Pretending that such is possible simply does not make sense. In our global society we have to interact with the opposite gender whether we live in a Muslim-majority country, or a Non-Muslim-majority country. Rather than just saying that men-women interactions are not permissible except when needed, the focus should be to provide guidelines and protocols to follow and abide by for when the time of 'need' arises. In this way, we can work on making every interaction professional and permissible in the sight of Allah. Since none of the classical Fiqh scholars dealt with this topic in the way we intend to, it has made my job very difficult in coming up with the guidelines and protocols of permissible interactions between men and women. To do so, we have begun by analyzing all the classical Islamic texts. The study is qualitative in nature and thematic content analysis is used to achieve the objectives of study. Conclusion of the study is significant in understanding the true picture of 
THE SCHOLAR (January- June 2020)

Islamic teachings for gender based social interaction.

KEYWORDS: Gender Interaction, Principles, Islamic Teachings, legitimize, intermixing

\section{INTRODUCTION:}

It is forbidden to intermix between men and women from an Islamic point of view, and this ruling is in general and what the majority of Muslim scholars followed. They discussed it in detail based on the texts mentioned in the Holy Qur'an, which clarify the controls of the conversation between the two parties. Among the details they discussed on the issue of emigration between the sexes is what the Prophet (PBUH) did in the farewell argument, where men preached on their own and then went to the women, so they engaged them alone, which means that it is not permissible to intermix with men and women. It is from this that the Holy Qur'an has commanded blindness and unsustainable consideration of women. It also includes not only speaking to women from behind a curtain, and likewise ordering women not to submit to speaking with men.

\section{CONCEPT OF GENDER BASED SOCIAL INTERACTION IN EDUCATION INSTITUTIONS:}

On the other side, the scholars have also made clear that there are cases in which it is permissible to speak with women about their own knowledge of Islamic matters. And listen; go to the mosque to perform the prayer. And to help the woman in fulfilling her needs if she is not able to do this on her own, as mentioned in the story of the daughters of the Prophet Shuaib, (PBUH), with the Messenger Moses, peace be upon him, as mentioned in the story of Moses when he went to the people of Median. We find that 
contemporary Muslim scholars have distinguished between mixing between men and women and communicating with or talking with them for the reason of necessity or what the spirit of reality and times requires as Muslim women have come out to the markets, mixed educational institutions, and go to the doctor for treatment, also, the woman has become a worker and an employee In banks, universities, and government institutions, which means leaving it to intermix with men or contact them for the purpose of practical fellowship or to satisfy the needs of the common people. In our study (Communication between men and women an Islamic point of view) we try to differentiate between the forbidden mixing from the Islamic viewpoint and the statement of the scholars 'sayings in it, and between the contact between men as well as women from what is necessary.

\section{INTERACTION OR INTERMIXING (اختلاط)-A GENERAL OVERVIEW:}

After reading some of the books of fiqh on this subject, we realized that the confusion regarding exchanges between men and women is being caused by not properly distinguishing between the terms 'interaction' and 'intermixing'. I would like to state that we are not in any way saying that none of the scholars of the past were unable to make such distinctions, and that I am the only one who has come to this conclusion. I seek refuge in Allah for saying that. Rather, the urgency that requires us to make such a distinction now was simply not present in the past like it is today. Nowadays Muslims go to colleges and universities where they have to interact with strangers from the opposite gender. They work in the environments where they have to interact with strangers from the opposite gender. Even in Islamic organizations you have to interact with strangers 
from the opposite gender. It is unreasonable for us to imagine a society in which such interactions never take place, and illogical to ignore the problem and deny its existence. We need the help of the scholars of today to give their time to things such as social media, where interactions between men and women are rampant and unregulated. It is incumbent upon us to recognize the differences between the two terms, and make rulings accordingly.

\section{GENDER BASED SOCIAL INTERACTION IN HISTORICAL PERSPECTIVES:}

It is requisite for us to continue in this text to understand differences between the terms that denote the exchanges and time spent between men and women; interaction and intermixing. These two cannot be mixed if we want to reach to our conclusion of understanding the guidelines of interaction. Though there are some instances in which both of these terms can be used interchangeably, in the context the Shari'a, we must consider them as two different terms to avoid any sort of confusion. We will use this instance to elaborate the difference between interaction and intermixing. It is reported in Sahih Al-Bukhari: "The Prophet (wav stood up and started with the (Eid) prayer, and after it he delivered the (Eid)

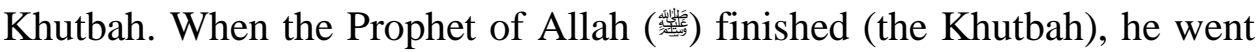
to the women and preached to them, while he was leaning on Bilal's hand. Bilal was spreading his garment and the ladies were putting alms in it." This Hadith clearly illustrates an interaction of the Prophet with female folks. The Prophet (1) in this instance went out of his way to remind the

1 Al-Bukhari included it in his Sahih, Book of Marriage, Chapter \{And Those Who Did Not Dream of You \}, No. 5249. 
women folks, deliberately entering into their midst along with Bilal. In our current times, our Imams and religious leaders cannot ignore the women folk, and should go out of their way to ensure that women in the audience understand the message of Islamic sermons clearly, as mentioned by Ataa. $^{2}$

On the flip side, the same Hadith can be used to say that general Intermixing (اختلاط) is not allowed, because men and women were in separate gatherings. This is implied because the Prophet had to walk towards the women, indicating that they were seated away from the men. There is an allusion to such a sentiment made by Haafiz Ibn Hajjar ${ }^{3}$ in his famous book: "Fath-Ul-Baari". 4

Since this book deals with the principles of interactions between both genders, it is important for us to take a brief look at what intermixing means linguistically. The literal meaning of intermixing in the Arabic language as explained by Ibn Manẓūr ${ }^{5}$ in "Lisān al- Arab"6. "It

2 Al-Bukhari included it in his Sahih, the Book of Eid, the chapter on walking and riding to the feast and prayer before the sermon without permission and residence, No. 918

${ }^{3}$ Abul Fadl Shihab al-Din Ahmad ibn Ali al-Kannani al-Asqalani, better known by the name of Imam Ibn Hajar, was born in Cairo in 773/1372. A Shafi'i scholar and hadith master, he studied under renowned scholars in Cairo, Yemen and the Hijaz. He authored more than fifty works on hadith, history, biography, Quranic exegesis, and poetry and Shafi'i jurisprudence; among the most famous of them is his fourteen-volume commentary on Sahih al-Bukhari called Fath al-Bari. He passed away in Cairo in 852/1449

${ }^{4}$ Fath al-Bari, Ibn Hajar, 2/366

${ }^{5}$ Ibn Manzūr was a North African lexicographer of the Arabic language and author of a large dictionary called Lisān al- 'Arab.

${ }^{6}$ Lisān al- 'Arab is one of the largest and most detailed dictionaries of the Arabic language. 


\section{Developing an understanding of gender based social interaction}

principles in Islamic teachings

means mixing; mixing of one thing with another." ${ }^{7}$ It also means: "gathering of different people... also it means sexual intercourse" 8 IbnFaris said in his famous book "Maqayes Al-Lughah" "It means neighbor or partner as Allah says in The Quran:

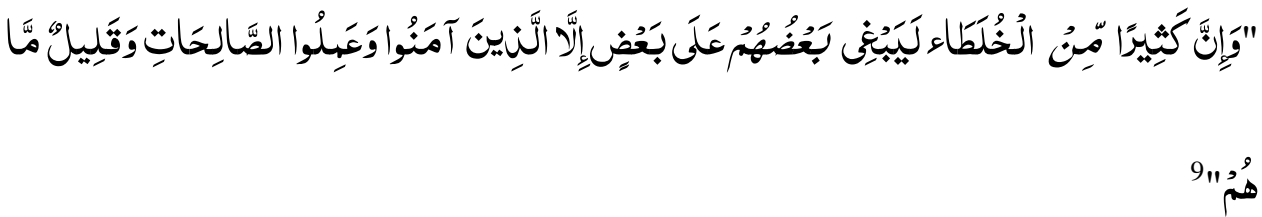

"And no doubt, many associates oppress one another except for those who believe and do good deeds." This word has a diverse meaning and is flexible enough to be used as the co-existence of two things, or a meeting and gathering of men and women in one place. ${ }^{10}$

MEANING OF INTERMIXING (اختلاط) IN ISLAMIC LAW:

Although some scholars believe that the term intermixing (اختلاط) does not exist in the classical books of Islamic text, ${ }^{11}$ the fact of the matter is that this word does exist in classical Islamic texts. ${ }^{12}$ Scholars have come up

7 Lisan Al-Arab, by Ibn Manzur, Article (Mixing), 7/29-295

${ }^{8}$ The Lexicon, Ibrahim Mustafa, Ahmed Hassan Al-Zayat, Hamed Abdel Qader and Muhammad Ali Al-Najjar, Article (Mixing), p. 294

${ }^{9}$ Surah Saad, Ayat 24

10 The mixing between men and women (its concept, types, divisions, provisions and harms), d. Saleh bin Fawzan bin Abdullah Al-Fawzan, p. 6 and mixing (the origin of evil in the destruction of nations and families), Abu Nasr Muhammad bin Abdullah Al-Imam, p. 29

11 A guide to male-female interaction in Islam, Dr.Hatem Al-Haj, page 28

12 The first evidence is that in the Sunnah the reference to the term mixing came, including from the hadith of Abu Asid al-Ansari, may God be pleased with him: "He heard the Messenger of God He says while he 


\section{Developing an understanding of gender based social interaction principles in Islamic teachings}

with a wide variety of definitions for the word intermixing (اختلاط) in the premise of Islamic law. One definition says: "A gathering of men and women who are strangers to each other at one place, who are talking to each other, and looking at each other, or trying to make physical contact." ${ }^{\prime 13}$ It is also said: "It is a gathering of men \& women seeking education, working, attending conferences and seminars" 14

If one makes use of this term in the above linguistic and connotative definitions and applies that meaning to the hadith where the Prophet Mohammad (睬) said:

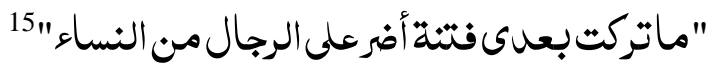

is outside the mosque: So the men mixed with women in the way, then the Messenger of God said to the women (they are retarded because it is not But if you check the road, you need the edges of the road) so the woman would stick to the wall, even if her garment was attached to the wall from her wallet, "Abu Dawood put it in his sunnah, No. 5272.

The second evidence: And the effect of Ibn Juraij said: Ataa told me, as Ibn Hisham prevented the women from circumambulating with the men. He said: How can he stop them when the women of the Prophet ( around with the men? I said: Farther or earlier? He said: What about my age? I realized it after the veil. I said: How do you mix with men? He said: He was not mixing with, Aisha was floating around a room of men not mixing with them. "Al-Bukhari included it in his Sahih, No. 1618.

The third evidence: Sheikh Saleh bin Fawazin said: The term mixing is well-known among the general interpreters, speakers, and jurists, as it has been proven that this term is defined by all scholars ... as he said in his book, "Mixing between men and women" on pp. 184-185.

13 The return of the veil, to Muhammad bin Ismail al-Muqaddam, 3/52 and prohibiting mixing, Al-Baddah, p. 9

14 Guarding the Virtue, Bakr Abu Zaid, p. 81 and prohibiting mixing and responding to those who permitted it, Abdul Aziz Al-Baddah, p. 9

15 Al-Bukhari included it in his Sahih, No. 5096 and Muslim in his Sahih, No. 2740 


\section{Developing an understanding of gender based social interaction principles in Islamic teachings}

"I have not left behind me a trial more harmful to men than women" then we as practicing Muslims would do well to ensure a distance between the source of the trial, the opposite gender, and the one being tried, ourselves. We would declare all such gatherings where intermixing (اختلاط) is happening as prohibited as a general ruling, and by default interactions would become impossible. But this is not the case, because we know that the Prophet (-5ithe interacted with the female companions of his time, and intermixing existed whenever there was a need for it, such as the gathering of Jummu'ah, Eid, and so on. ${ }^{16}$

\section{DISCUSSION:}

As a matter of fact, Imam Nawawi ${ }^{17}$ (رحمه الله) said in his famous book alMajmu' sharh al-Muhadhdhab ${ }^{18}$ regarding permissible kinds of intermixing (اختلاط): “There is a consensus that

\section{ANALYTICAL APPROACH OF STUDY:}

Historical thematic content analysis has been used to achieve the objectives of the study. For this purpose, principles of gender based social interaction has been critically analyzed in historical perspectives. It is permissible for a woman to attend and pray the Friday congregational prayer, since it has been established in a great number of authentic Hadith

\footnotetext{
${ }^{16}$ A guide to a male-female interaction, Dr.Hatem A-Haj, page 28

${ }^{17}$ Abu Zakaria Yahya Ibn Sharaf al-Nawawī (631-676 A.H./1234-1277), was an influential Shafi'ite jurist and hadith scholar. He authored numerous and lengthy works ranging from hadith, to theology, biography, and jurisprudence.

18 al-Majmu' sharh al-Muhadhdhab is a comprehensive manual of Islamic law according to the Shafi'i school.
} 


\section{Developing an understanding of gender based social interaction principles in Islamic teachings}

that women used to pray behind Allah's messenger (nis mosque, behind the men. This is also because the intermixing (اختلاط) of women with men is not prohibited, provided that it is not in seclusion." 19 Succinctly, we cannot issue a general ruling of prohibition, nor can we make permissible general intermixing (اختلاط) because there are a wide variety of things to consider before issuing a fatwa (ruling). Such considerations include the precise situations, circumstances, need for intermixing (اختلاط), and so on. For detailed discussions on intermixing (اختلاط), I would recommend the reader to read the book "A Guide to Male-Female Interactions in Islam" by Dr. Hatem Al-Haj. We already mentioned earlier that our focus will be on the guidelines of interaction more than the academic discussion thereof. This is because of the simple fact that interactions (اختلاط) are far more relevant to the average Muslim of today than the judicial minutia of intermixing (اختلاط). Our focus is also due to the fact that many scholars wrote about intermixing (اختلاط) previously, but very rarely did they weigh in on the principles of, and guidelines for interactions. The first principle we should keep in mind whilst interacting with the opposite gender is that we should have 'respect in our eyes', by not giving lustful looks to each other, and/or avoid staring at others from the opposite gender.

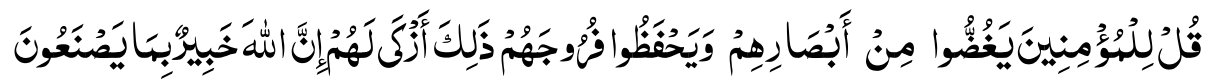

19 Total, 4/404 


\section{Developing an understanding of gender based social interaction principles in Islamic teachings}

"Tell the believing men to lower their gaze (from looking at forbidden things) and protect their private parts (from illegal sexual acts, etc.). That is purer for them. Verily, Allah is All-Aware of what they do."20

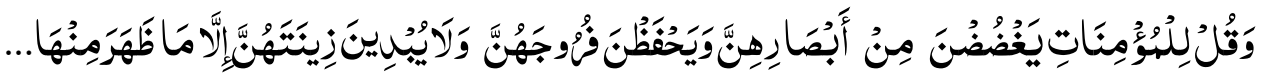

"Tell the believing women to lower their gaze (from looking at forbidden things) and protect their private parts (from illegal sexual acts, etc.) and not to show off from their adornment except only that which is apparent..."21

We can see from the above-mentioned verses that Allah s.w.t. is asking both the believing men and women to lower their gazes, but do we have to keep our gazes lowered all the time? Does this mean that we're not supposed to see each other at all? We will examine the evidences regarding this matter from the linguistic, prophetic and juristic ${ }^{22}$ perspectives In Shaa Allah. We see in this verse of Surah An-Nur, that Allah s.w.t. asked the believing community to control their gaze by using the word: مِن

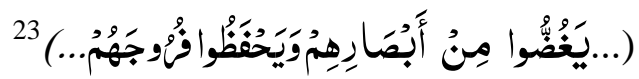

"Lower from their gazes and protect your privates". It's very interesting that Allah s.w.t. used the preposition مِ (from) when speaking about lowering the gaze. The word 1 is used for 'a fraction of' or 'a part of'

${ }^{20}$ Soorah An-Noor, Ayat 30

${ }^{21}$ Soorah An-Noor, Ayat 31

22 (From Fiqh Stand point)

${ }^{23}$ Surah An-Nur, Ayah 30 
according to most scholars ${ }^{24}$. What this means put simply, is that we don't have keep our gaze lowered all the time (which is not even rational or possible). Instead, we should lower our gaze whenever we see something inappropriate, and not have our heads/eyes pointed downward at all times. Perhaps even more interesting is that Allah s.w.t. didn't use this style when he asked the believers to protect their privates, for e.g. he didn't say:

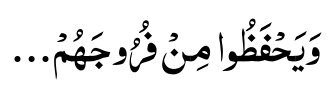

Rather, He said that we have to protect our privates (completely) without any exception. This is evident because he didn't use the preposition (from). Another linguistic point to note here is that the same style is used for "lowering your voice" in Surah Luqman, Allah s.w.t. says:

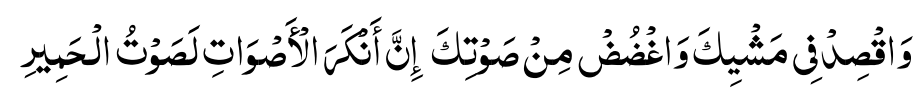

"Go at a moderate pace and lower from your voice, for the ugliest of all voices is the braying of donkeys" 25 . The advice being given in this verse is to not sound arrogant and inconsiderate when dealing with people. Clearly, the ayah isn't asking us to stay quiet all the time, or to speak in a low voice at all times. We know this because the Prophet use to raise his voice while giving the Friday Khutbah (sermon) ${ }^{26}$. Therefore, this ayah cannot be commanding us to remain quiet or soft-spoken at all times.

24 See Tafsir Al-Qurtubi, vol. 12, pp. 202-203 and Tafseer Al-Razi, vol. 23 , p. 361

${ }^{25}$ Surah Luqman, Ayah 19

${ }^{26}$ It was included by Muslim in his Sahih, Kitab al-Jumu', Chapter on Reducing Prayer and Sermon, part 2, p. 592, No. 867. 
Similarly, it is unreasonable to say that the phrase "lower your gaze" means to keep your gaze lowered at all times. Instead, we use linguistics to discover the true meaning, which is that we should avoid looking at any sort of inappropriate things ${ }^{27}$. The Prophet Mohammad (nstructed his companions to avoid looking at the opposite gender inappropriately. He (彩) said:

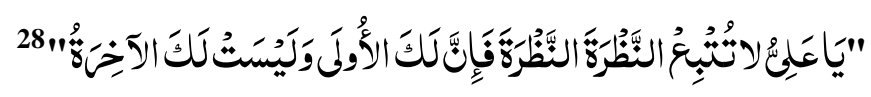

"O Ali, do not follow a glance with another, for you will be forgiven for the first, but not for the second." From this we can infer that whenever an individual is talking to a stranger from the opposite gender (NonMahram $)^{29}$, then he/she must remember these instructions from Allah s.w.t. and the Prophet (

It is the consensus of all the scholars of Islam that: It is prohibited (haram) to look at a stranger of the opposite gender with the intention of sexual desire (الشهوة) or temptation (خوف الفتنة) at the privates or ' $a w r a h^{31}$ of another in almost all circumstances, with the only exception being that of a dire need, which we will mention later on in

${ }^{27}$ What constitutes as inappropriate in Islamic law will be defined later in this chapter.

28 It was included by Abu Dawood in his Sunnah, in the chapter on what is ordered by turning a blind eye, part 2, p. 246, No. 2149, al-Albani ruling: Hassan

${ }^{29}$ (For a detailed list of Mahran \& Non-Mehram for men and women, see Appendix A)

${ }^{30}$ See Kuti Fiqh Encyclopedia, Vol. 26, p. 269

${ }^{31}$ Awrah: the part of body which needs to be covered all the time. For men it is the navel to the knee, and for women it is the entire body, except the face and hands up to the wrist (and feet according to some scholars). 
The Scholar Islamic Academic Research Journal

Vol. 6, No. 1 || January-June 2020 || P.189-219

https://doi.org/10.29370/siarj/issue10ar14

this chapter. Ibn-Taymiyyah said about this: "Allah s.w.t. has enjoined on us in His Book to lower the gaze, which is of two types: refraining from looking at the 'awrahs and refraining from looking at the site of desire. The former refers to a man refraining from looking at the 'awrah of another person. The second refers to looking at any uncovered parts of a non-mahram woman (when speaking about a man's gaze)." ${ }^{32}$ Can we make an eye contact whilst interacting with the opposite gender? Or look at the face? Eye contact is an integral part of communication, but when it comes to talking to strangers of the opposite gender, our classical scholars disagree on whether or not an individual can look at the face of another (who is non-Mahram). Some of them gave permission with the condition that it should not be done with any sort of sexual desire (الثهوة) or temptation (خوف الفتنة). Some scholars said it is disliked (Makrooh) some scholars said it is prohibited. (Haram) ${ }^{33}$

The following are the two opinions which have come out of the discussion between scholars on the matter. To keep your gaze lowered and avoid looking at the face (of a non-Mahram) because it's prohibited, or at the very least disliked, even if there is no desire or temptation. The only exception being when there is a dire need. (For details: see the

32 Ibn Taymiyyah said in Majmoo 'al-Fataawa: "And God Almighty has commanded in his book the loathing of sight. It is of two types: turning a blind eye to the' awrah.

${ }^{33}$ Ibn Al-Qattan said in his book "Rulings of Looking": As for the issue of his looking at her face: some of them are: from his nuts \{ at all, and some of them: who authorized him) not at all, but he is bound to not fear (by looking at) the fitna, and some of them: who forbid it at all, and some of them: Whoever made it hateful ... This is how Ibn Al-Qattan wrote in "The Rulings of Looking at the Rulings of Looking Sight, p. 388 
$\overline{\text { footnotes }^{34} \text {. It is permissible for a man/woman to look at each other's }}$ faces or any other part which isn't part of the 'awrah, provided there are no sexual desires (الثهوة) of any sort or temptation (خوف الفتنة). (For details: see the footnotes) ${ }^{35}$

Considering the aforementioned, we can say that there is nothing wrong in making eye contact in general circumstances, but it is better to avoid it and follow the conservative opinion whenever there is a potential for temptation/desire. An example being if you must interact with a younger, attractive individual $^{36}$, or if the individual is not well covered. Allah knows the best. Even though there is some scholarly disagreement about the permissibility of looking at the face of a stranger of the opposite gender in general circumstances, scholars agree that it becomes permissible to look at the face (without desire) at the time of a 'necessity' (ضرورة). All of the four schools of thought agree on this. A 'need' can include, but is not limited to, buying, selling, education, medical treatment, court witnesses, marriage proposals and so on. ${ }^{37}$ Please note that at the

${ }^{34}$ This is According to one opinion of Imam Maalik, one opinion in the Shafi'i Madhab and one opinion of Imam Ahmed. The following is the evidence for it:

35 This is according to Hanafi Madhhab (earlier scholars of Hanafi Madhab), one opinion of Imam Maalik and one opinion of Imam Shafi'i and one opinion of Imam Ahmed. The following is the evidence for it.

${ }^{36}$ There are some Jurists who gave importance to being less flexible when it comes to younger, more attractive women. Like in the Hanafi Fiqh:

37 The following are the evidences.

- Imam al-Nawawi said: "If it is a legitimate need, it is permissible to consider, as in the case of selling, buying, medicine, testimony, and the like, but it is forbidden to consider this case with desire, then the need permits consideration of the need for it, and as for 
times of need, in some circumstances it becomes permissible not only to see the face, but other parts of body as well. For example, a doctor looking at the body of patient for medical treatment. ${ }^{38}$

This is the second rule when interacting with the opposite gender; that conversation should be useful and not unless. We can see during the time of the Prophet Muhammad PBUH that both men and women interacted, but within guidelines. Rationally \& psychologically speaking it's not possible to have a functional society without any sort of interactions between men and women.

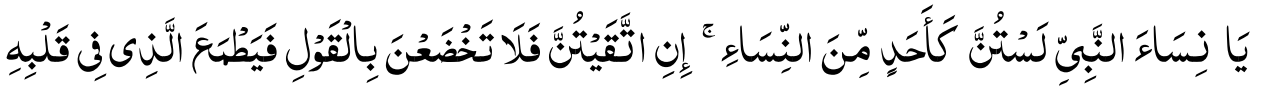

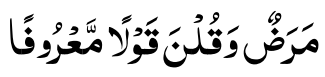

"O wives of the Prophet! You are not like other women. If you keep your duty (to Allah), then be not soft in speech, lest he in whose heart is a disease should be moved with desire, rather speak in an honorable manner". ${ }^{39}$ Notice that in this aya Allah didn't say "do not speak to men at

desire, there is no need for it" in his curriculum book Explanation of Sahih Muslim, Vol. 4, p. 31

Imam al-Suyuti said: "The need descends the rank of necessity (and necessities permit prohibitions) ..." in his book Al-Asbah and Al-Nazaer, p. 88.

38 Ibn Qudamah al-Maqdisi al-Hanbali said: Chapter: It is permissible for someone to look at it from foreigners. It is permissible for the doctor to look at what is needed from her body, from the 'awrah and other things, because it is a matter of need ... If a woman worker is selling or leasing, he may look at her face, To teach her by herself, so he turns her back to the gendarmerie, and it was narrated that Ahmad hates it in the right of the young woman without the old woman. In his book Al-Mughni by Ibn Qudamah, chapter: It is permissible to look at foreigners, vol. 7, p. 101 ${ }^{39}$ Surah Ahzab, verse no. 32 
all", instead He said "do not be soft in your voice... And speak to them in honorable manner". 40 This aya clearly illustrates that conversation between men and women in and itself is not prohibited, but there are guidelines which we have to abide by. Tone Should Be Professional and Not Tempting ${ }^{41}$. Even though a woman's voice is not the part of her 'awrah (the parts of her which need to be covered) ${ }^{42}$ the above-mentioned aya suggests that her voice should not be made very soft and/or tempting. However, the aya does mention speaking honorably. This means that if a woman is not making her voice soft, she still needs to speak in a manner that does not insult or cause offense. Certain women have naturally soft voices. This doesn't mean that they can't speak to men at all as a result. The aya is referring to making a tempting voice to get the attention of men. Flirtatious women used to do this to get the attention of men during the Pre-Islamic era in the Arabian Peninsula. ${ }^{43}$

1) Conversations Should Be Professional ${ }^{44}$

40 The Sheikh Al-Uthaymeen said: "God Almighty did not say then men did not speak, but he said, do not submit by saying, and submitting to saying is more special than the utterance of words. So the woman's words to the man if there is no fitna there is nothing wrong with it" in his book Mgmuh questions that concern the Muslim family, p. 37

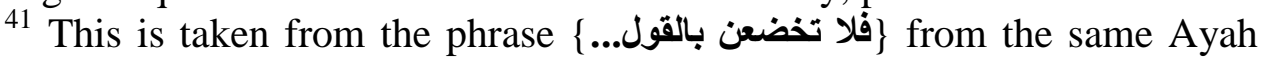
i.e. Surah Ahzab, Verse 32

${ }^{42}$ It is extremely important for us to mention this fact that majority of the traditional scholars said that the women voice is not part of her Awrah.

Following is the evidence.

Ibn Najim al-Hanafi, The Clear Sea, Explanation, Treasure of the Minutes, Part 1, p. 285

43 Al-Qurtubi, Al-Jami Al-Ahkam Al-Qur'an, vol. 14, p. 177

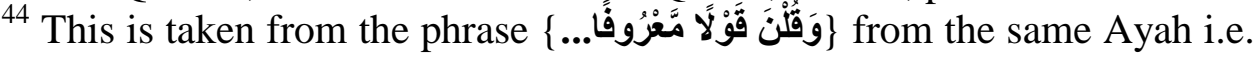
Surah Ahzab, Verse 32 
The Scholar Islamic Academic Research Journal

Vol. 6, No. 1 || January-June 2020 || P.189-219

https://doi.org/10.29370/siarj/issue10ar14

If the conversation is limited to only what is necessary without branching off into other (unnecessary), topics then there is no fault or sin, as there are numerous examples from the Quran \& Sunnah that reference these kinds of interactions.

The word "لقول" in Arabic can be interpreted for both verbal and nonverbal expressions. This word can even be used for the thoughts which comes in our heart that we don't express with the tongue ${ }^{45}$. Thus, even in non-verbal communication, we are told to maintain an air of dignity. During non-verbal communication, we need to make sure that we are not using any indecent vocabulary, and we should not be using unnecessary emojis or indecent internet slang. There is nothing wrong with saying the Islamic greeting "Salam" to strangers of the opposite gender in general circumstances, as well as responding to $\mathrm{it}^{46}$. We as Muslims are encouraged to do so by the Quran \& Sunnah. ${ }^{47}$ It is narrated in Abu Dawood: "The Prophet PBUH passed by us woman and greeted us with salaam." ${ }^{48}$ He made his camel kneel down and put his foot on its foreleg (to keep it steady), then I mounted it, and he set off, leading me on the mount, until we came to the army." Sahih Al-Bukhari. ${ }^{49}$

4545 Imam Ragheb said: "The person who is perceived in the soul is told before highlighting the word: a saying, and he says: I have a saying that I have not revealed... so he made what they believed in a saying" in his book, Vocabulary of the Qur'an, p. 688.

${ }^{46}$ The only exception is that when there is young stranger opposite gender and there is a fear of temptation with that then its not encouraged to say salam or to respond to it. Following is the evidence for it.

${ }^{47}$ Surah An-Nisa, Ayah 86

48 It was included by Abu Dawood in his Sunnah, Chapter on Peace be upon Women, part 4, p. 352, No. 5204, Al-Albani Rule: Sahih

49 Al-Bukhari included it in his Sahih, No. 4750, c. 6, p. 101 
The Scholar Islamic Academic Research Journal

Vol. 6, No. 1 || January-June 2020 || P.189-219

https://doi.org/10.29370/siarj/issue10ar14

Al-'Iraaqi ${ }^{50}$ said in the explanation of this Hadith: "He did not speak to her; rather he used silence in that situation out of good manners and politeness, and because of the seriousness of the situation in which he found himself. This hadeeth also shows us and example of good manners with non-mahram women, especially in the case of being alone with them out of necessity in general circumstances. It shows verbal as well as nonverbal manners, such as when Safwaan made his camel kneel without speaking or asking (unnecessary) questions." ${ }^{, 51}$

Take note of the balance of Safwan; he didn't say that I can't help 'Aisha because it's Haram, nor did he needlessly over engage her. Instead he helped our Mother 'Aisha by abiding to the guidelines of Shari'ah. It's an undeniable fact that physical contact with the intention of sexual desire (1) is prohibited according to all scholars. It is reported by Al-Tabaraani in a Sahih Hadith that the Prophet PBUH ( said:

${ }^{50}$ Al-Hafiz Zain al-Din 'Abd al-Rahim al-'Iraqi (725/1325-806/1404) was from a Kurdish family and born in Iraq. He later moved to $\underline{\text { Cairo. }}$. He became one of the leading Shafi'i scholars and scholars of hadith at his time.

51 Abu al-Fadl al-Iraqi said in the chapter "The Benefit of Literature with Foreigners, Especially in Retreat": "It did not happen from him, but I used silence in this case as literature and maintenance, and for the sake of that situation in which it is in which the relief of the deaf, the aid of the interrupted, the rescue of the lost, the honor of the people of fate, and the good manners with the foreign women Especially in being alone with them from necessity in the wilderness or elsewhere, as Safwan did, when he blessed the camel without words and no question, and he should walk before it, not next to it or behind it, and it is mustahability to ride altogether. In his book, Al-Turathbi Explained in Sharh al-Taqrib, vol. 8, p. 53 


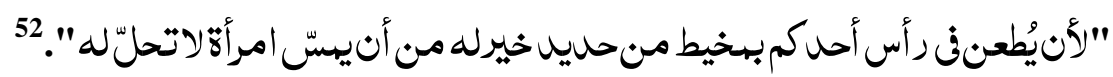

"If one of you were to be struck in the head with an iron needle, it would be better for him than if he were to touch a woman he is not allowed to." The word for touching in the hadith is "يمسّ" means in the context of Shariah sexual intercourse. ${ }^{53}$

All of the scholars agree that if there is a genuine need to touch a stranger of the opposite gender, then it is permissible for e.g. a doctor touching the part of patient's body necessary for the treatment. ${ }^{54}$

1) Without sexual Desire ${ }^{55}$ :

Often in Western countries, Muslims face the predicament where someone from the opposite gender will initiate their hands to shake in a greeting etc.

52 It was included by al-Tabarani in his great lexicon, Bab Mim, vol. 20, p. 211, No. 486, classed as saheeh by al-Albani in Sahih al-Jami 5045.

53 Imam Ragheb said: "Be with him about marriage, and it was said: $\mathrm{He}$ touched it and touched it. The Almighty said: If you divorce them before you touch them [Al-Baqarah / 237]," he said: "No wings are upon you if you divorced." You did not touch them, and he said: "I have a child and no one touches me [Al-Imran / 47] and the politician is a metaphor for marriage ..." in his book, Vocabulary of the Qur'an, p. 767.

54 I See the Kuwaiti Jurisprudence Encyclopedia, Part 2, p. 290 and Ibn Abdin, Part 1, p. 272 and the similar analogues to Ibn Najim, p. 95 and AlHattab, Part 1, pp. 499-500 and Al-Manthor Al-Zarkashi, Part 2, p. C 6, p. 658 and the scout of the mask, C 5, p. 13

${ }^{55}$ Someone might ask that from the Shairah perspective that where do we get these distinction of with sexual desire and without sexual desire? One might have misunderstanding and say our classical scholars doesn't made any of such distinctions which we are making. The answer to this question will be that in fact our classical scholar of Fiqh came up with such distinction. As a matter of fact in the Hanafi Fiqh, it is said it is okay to shake hand with the old women when there is no sexual desire and temptation. See the following evidence: 
and they don't know what to do. Even in Muslim-majority countries, sometimes an individual in a family will put his/her hand on the head of a younger stranger of the opposite gender as nothing more than a cultural interaction. If we assume that such an interaction won't include any sexual desire, then what does Islam say about it? What is the ruling? Is it prohibited (Haraam) or disliked (makrooh)? What about avoiding the embarrassment of the other person?

It is also mentioned in Sahih-Bukhari, the Prophet (4id not hold the hands of women when accepting their bay'ah, as he did with men; their bay'ah was by words only.

'Aa'ishah said: “The hand of the Messenger of Allaah (㯊) never touched the hand of any woman except a woman he owned." 56

We can clearly see from the above-mentioned narrations ${ }^{57}$ that the Prophet (政) neither shook hands with women nor did he touch them. But the above-mentioned narrations do not reach the level of prohibition because it is known that the Prophet's leaving of a matter did not necessarily indicate that it was prohibited, as he may have left something because it was prohibited (haram) or disliked (makruh).

Based on this analysis, a practicing Muslim should refrain from shaking the hands of strangers from the opposite gender because the opinion

56 Al-Bukhari included it in his Sahih, Book of Rulings, Bab Al-Nisa Women, volume 9, p. 80, No. 7214

${ }^{57}$ Some scholar also use this Hadith which we already narrated earlier: "If one of you were to be struck in the head with an iron needle, it would be better for him than if he were to touch a woman he is not allowed to." Al-Tabaraani.

But as we already narrated that word in this hadith is used for sexual intercourse. Please refer to page no. 
regarding it is at least that it is disliked. Therefore, we should never be the first one to extend our hands.

Let's say you were pressured into shaking hands with someone in the work environment (either because of social pressure or to avoid embarrassment). In that case we hope that Allah will forgive you, but make sure to convey in a kind and polite way to that individual (if there is potential of more than one interaction) that due to religious guidelines you would be more comfortable if physical contact were avoided.

In order to have a permissible interaction between a man and a woman in Islam (that are non-Mahram), we should always meet in a public place and avoid meeting in private. Prophet Muhammad PBUH said:

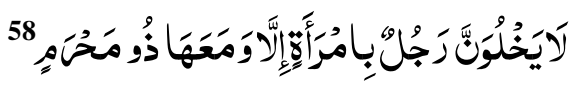

"No man should be alone with a woman unless there is a mahram with them"

It is also narrated in Sunan Tirmidhi:

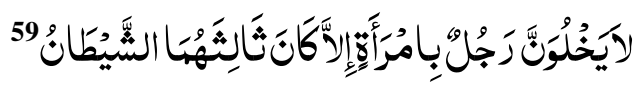

"No man is alone with a woman except the devil is the third one present." Meeting in private (خلوة) refers to a place where a man and a woman are together in a place where no one can see them ${ }^{60}$. This is considered to be

58 Al-Bukhari included it in his Sahih, a chapter that does not evacuate a man with a woman except Dhu Muharram, vol. 7, p. 37, No. 5233

${ }^{59}$ It was included by al-Tirmidhi in his Sunnah, the chapter on what came in the hatred of entering on ..., part 2, p. 465, No. 1171, classed as saheeh by al-Albani in Sahih al-Tirmidhi.

Kuwaiti Jurisprudence Encyclopedia, Vol. 5, p. 207, Ibn Muflih, Branches, Vol. 5, p. 153 
The Scholar Islamic Academic Research Journal

Vol. 6, No. 1 || January-June 2020 || P.189-219

https://doi.org/10.29370/siarj/issue10ar14

Haram according to all of the schools of thoughts. ${ }^{61}$ This means that a man and a woman cannot meet in a private setting, even if they have to discuss something useful and even if they assume that there will not be any sort of temptation. The better option is to meet in public. Let's say you have to meet with someone privately, what should you do? You must make sure to have someone with you (a third person) to make that meeting legitimate. ${ }^{62}$ We know now that we can't meet in private because the third one present will be shaitan, ${ }^{63}$ but what about meeting in the virtual world, like texting, emailing, chatting on instant messengers, etc. where it's as private as a virtual room? Our best option is to view this virtual privacy as we would the private meeting of reality. Therefore, we should add someone to the chat, group, etc., that would legitimize the interaction. Perhaps this is the closest way of the Prophetic form of interaction. But if there is a need, or if it becomes impossible to do so because of the nature of one's work, then we believe that this will not be sinful as long as the person is interacting without any sexual desire or temptation.

It is important to follow the guidelines outlined in this book, particularly for physical meetings, as privately interacting with each other whilst not

${ }^{61}$ Imam al-Nawawi said: "Prohibition of being alone with a non-mahram woman and permitting being alone with her mahrams, and these two matters are unanimously agreed upon..." in his book Sharh Sahih Muslim, vol. 14, p. 153.

${ }^{62}$ Following is the evidence:

Al-Nawawi wrote: "The famous is that it is permissible for a man to be alone with a woman who is not forbidden by them, because the spoil is often not because women are ashamed of each other in that 87 "...

63 It was included by al-Tirmidhi in his Sunnah, the chapter on what came in the hatred of entering on ..., part 2, p. 465, No. 1171, classed as saheeh by al-Albani in Sahih al-Tirmidhi. 
looking at each other in virtual world (خلوة الحديث), is less dangerous than privately meeting and interacting while looking at each other in real world (خلوة النظر). This is indicated in one of the narration in Sahih Al-Bukhari where a woman came to Prophet with her baby to discuss something personal while Prophet (with Prophet privately while other companions couldn't hear her conversation. ${ }^{64}$ I am writing this chapter with two objectives in my mind: To clarify that the interactions between men and women are not in and of themselves haram because the Prophets and companions interacted with the opposite gender (within certain guidelines), and they are the best role model for us. To eradicate some of the misconceptions about the following verses pertaining to men-women interactions. Allah s.w.t. mentions in glorious Quran when the angels visited Ibrahim's house:

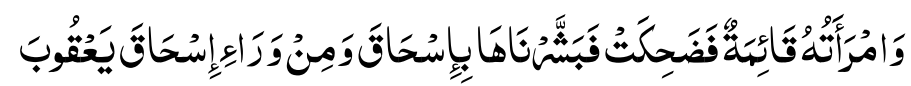

"And his wife was standing and she smiled, then we gave her good tidings of Isaac, and after Isaac, of Jacob" ${ }^{, 65}$. We can see here that the wife of Ibrahim (was standing before the honored guests and a useful interaction was taking place. What's more is that Ibrahim (A.S.) didn't react negatively to this. Also, we know the following: Sarah (wife of Ibrahim) was very old. Allah explained in Surah Ad-Dhariyat:

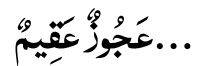

\footnotetext{
64 Al-Bukhari included it in his Sahih, the chapter on what is permissible for a

vol. 9 P. 333

${ }^{65}$ Surah Hud, Ayah:71
} 
"A barren old woman." Ibrahim (A.S.) and his wife were aware of the fact that they were interacting with the Angels. This conversation wasn't taking place in private and Ibrahim (A.S.) was there as well so there is no chance of abusing this conversation or taking it out of context. "...Every time Zakariah went to her in the prayer chamber, he found with her provision. He said "Oh Mary, from where is this (coming) to you? She said, "It is from Allah. Indeed, Allah provides for whom he wills without account." We can see that there is a useful interaction taking place between Mary and Zakaria (4). But one might ask, even if the conversation is useful, why they are meeting alone? Well, we need to know a few facts about Zakaria ( Zakaria (s the husband of Mary's maternal aunt. He is also a custodian of Mary. He has also reached a very old age during the time of this conversation, as he himself mentioned in Surah Maryam

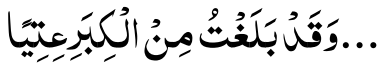

“...And I have reached extreme old age."67

Allah s.w.t. says in Surah Al-Qasas:
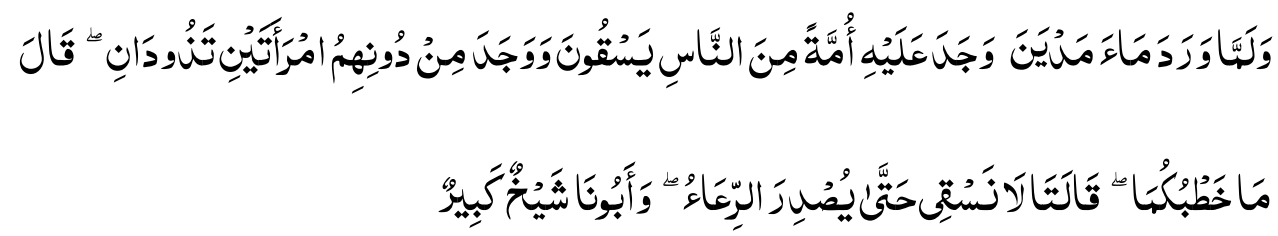

"And when he came to the well of Madyan, he found there a crowd of people watering (their flocks), and he found aside from them two women

${ }_{67}^{66}$ Surah Ad-Dhariyat, Ayah: 29

${ }^{67}$ Surah Maryam, Ayah 8 
driving back (their flocks). He said, "What are your circumstances?" They said, "we do not water until the shepherds dispatch (their flocks); and our father is an old man."68 The abovementioned verse clearly illustrates that

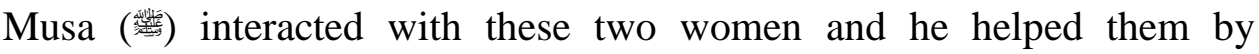
watering their flocks after finding out that their father was an old man (unable to assist his own daughters in watering the flocks). This is also an ideal example of how men and women should interact in the workplace, as there are many parallels between this incident and the modern workplace. Take a look at the following reasons: The verse shows that the two women did not want to interact with the men they knew would be at the watering area because they explained to Musa (A.S.) that their father was an old man. ${ }^{69}$ This indicates that they viewed the presence of strange men as an obstacle they had to navigate whilst trying to help out their family. The previous notion is further reinforced by the mention of the two women holding their animals back to avoid intermingling with the men. ${ }^{70}$ Musa (1) didn't engage in any unnecessary conversation with them. ${ }^{71}$

Also, in the same Surah, when the old father sent one of the daughters to invite Musa (or compensation, Allah s.w.t. says:

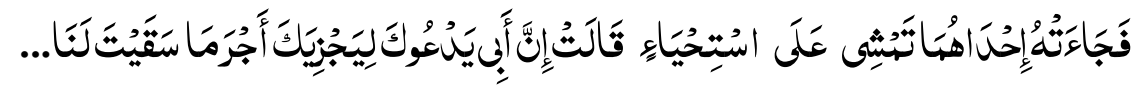

"Then one of the two women came to him walking with shyness. She said, "Indeed, my father invites you that he may reward you for having watered

\footnotetext{
${ }^{68}$ Surah Al-Qasas, Ayah 23

${ }^{69}$ See al-Razi's interpretation, vol. 24, p. 589

70 Imam Al-Razi said in his interpretation: "So as not to mix with men", vol. 24 , p. 588

${ }^{71}$ See Tafsir Al-Qurtubi, vol. 13, p. 239
} 
for us..."72 This is also a great example of men-women interactions

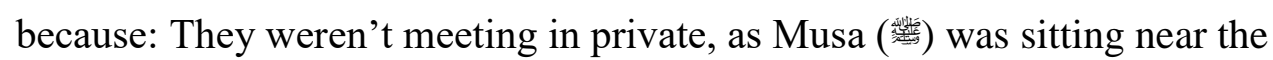
well under the shade of a tree. ${ }^{73}$ The pious Father of the woman trusted her and sent her to interact with Musa (敬) ${ }^{74}$

When Musa accepted the invitation, he walked in front of the woman to control his gaze. ${ }^{75}$ The two did not engage in any useless conversation. Her shyness is highlighted more here because she is alone in this instance, as compared to the last conversation where she was with her sister. Prophet Muhammad's (nteraction with Khawlah in Surah AlMujaadilah: Allah s.w.t. said in the beginning of Surah Al-Mujaadilah:

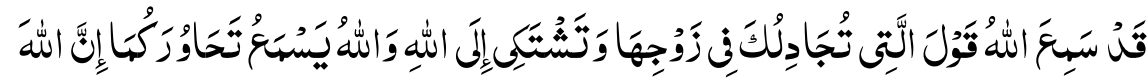

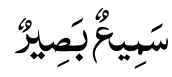

"Certainly, Allah has heard the speech of the one who argues with you, [O Muhammad], concerning her husband and directs her complaint to Allah. And Allah hears your dialogue; indeed, Allah is Hearing and seeing.,"76 Before we can understand the interaction between Prophet Muhammad (瞵) and the woman in the above-mentioned ayah, we must acquaint ourselves with some of the historical facts pertaining to this Ayah: This Ayah was revealed about Khawlah bint Tha'laba who was married to Aws ibn As-Samit. One day, they had an argument and Aws divorced her by

\footnotetext{
${ }^{72}$ Surah Al-Qassas, Ayah 25

${ }^{73}$ Surah Al-Qassas, Ayah 24

${ }^{74}$ See Tafseer al-Razi, vol. 20, p. 590

75 See Tafsir Al-Qurtubi, vol. 13, p. 241

${ }^{76}$ Surah Al-Mujaadilah, Ayah 1
} 
Dhihar $(ظ)^{77}$. This kind of divorce frees the husband of his responsibilities towards his wife and children, and prevents the wife from ever remarrying him. ${ }^{78}$ Khawlah came to Prophet Muhammad (新) to seek help and guidance about her personal marital issue. There are a few things

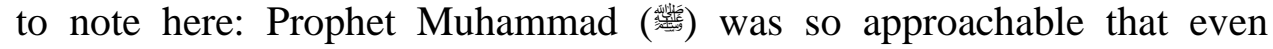
woman folk could reach out to him to seek counsel for their personal matters, provided that they followed certain guidelines. Neither Allah s.w.t. nor Prophet Mohammad ( objected to her coming to him. It was a useful conversation because Khawlah had a genuine need. This interaction is taking place in public, as Aisha is the one who narrated this Hadith. She herself said that she was an old woman, as Aisha explained that when

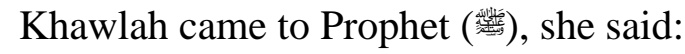

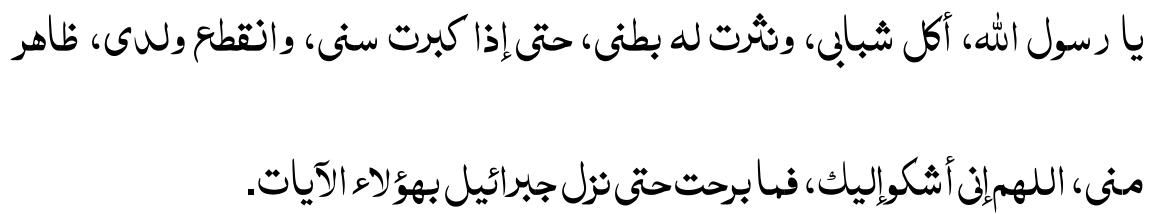

"O Prophet of Allah, he has consumed my youth, and I split my belly for him (i.e. bore him many children), but when I grew old and could no longer bear children he declared Zihar upon me; O Allah, I complain to you. She continued to complain until Jibri'l brought down these verses.",79 Interactions in the Sunnah: We see in the life of Prophet Muhammad (W-5 that he did indeed interact with the female companions. It is impossible for

77 Thihar (ظهار): a Pre-Islamic Arab custom of divorcing a wife by saying, "Be to me as my mother's back."

${ }^{78}$ Interpretation of Al-Qurtubi, vol. 17, pp. 229-231

${ }^{79}$ Narrated by Ibn Majah in his Sunan, Bab Al-Dahr, part 1, p. 666, No. 2063, Sahih Abdul-Albani 
me to mention all of those interactions, but I will mention just a few of those that might be relevant to the theme of this book, and at the same time

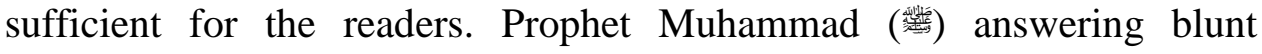
questions from female companions: Sometimes, female companions would ask very straight forward questions to the Prophet PBUH. It was narrated from Zaynab, the daughter of Umm Salamah, who said: Umm Sulaym

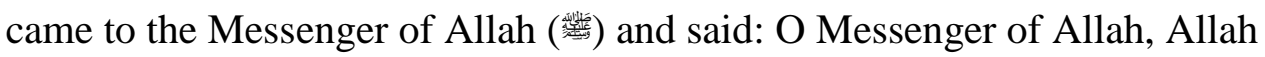
is not too shy to tell the truth. Does a woman have to do ghusl if she has an erotic dream? The Prophet (繁) responded: "Yes if she sees the fluid". ${ }^{80}$ Something to note about this interaction: It was done in public as the wife of Prophet Muhammad (was there ${ }^{81}$. It was a useful conversation because it was a religious inquiry. She said in the beginning: "Allah is not too shy to tell the truth" as a disclaimer, or as a sort of apology before asking her question, for which there was a need. The disclaimer is because it was regarding something that women usually felt shy to ask about and mention in the presence of men. That is why Imam An-Nawawi said in the explanation of the same hadeeth that it is appropriate for the one who has a question to ask it, and not to refrain from asking out of shyness. That refrain is not really shyness, instead this is lack of confidence, because all shyness is good and shyness does not lead to anything but good. However, refraining from asking in this case is not good, rather it is bad, so how can it be shyness? ... Aisha said: How good were the women of the Ansar;

80 Al-Bukhari included it in his Sahih, Book of Knowledge, Chapter of Modesty in Knowledge, Part 1, p. 38, No. 130 and Muslim included in his Sahih, Book of Menstruation, Chapter on Obligation to Wash Women on Exodus from Semen ..., Part 1, p. 251, No. 313

81 See Sharh al-Nawawi Ali Muslim, part 3, pp. 219-220 
shyness did not prevent them from understanding matters of their religion. And Allah knows best. ${ }^{82}$ Sometimes female companions would ask such

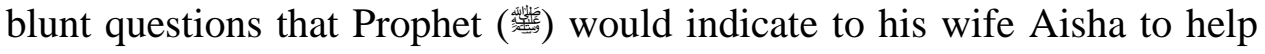
out due to his shyness. ${ }^{83}$

\section{RECOMMENDATIONS:}

There is a difference of opinion regarding whether or not an individual can look at the face of a stranger from the opposite gender whilst interacting with them amongst the scholars. This is the second rule when interacting with the opposite gender; that conversation should be useful and not unless. We can see during the time of the Prophet Muhammad PBUH that both men and women interacted, but within guidelines. Rationally \& psychologically speaking it's not possible to have a functional society without any sort of interactions between men and women. Nowadays we can communicate with each other on social media or other text-based mediums, most of which contain conversation that is comprised of nonverbal expression e.g. emails, text messaging, etc. Firstly, we need to understand that the prohibition of shaking hands with a stranger from the opposite gender comes under the Fiqh principle of "prohibiting the means which lead to the ultimate prohibition". Thus, shaking hands is prohibited because it can lead to fornication. Something which is prohibited because it may lead to major sin is a lesser evil when compared to something that

82 See Sharh al-Nawawi Ali Muslim, part 3, p. 224.

83 It was included by a Muslim in his Sahih, "The Book of Menstruation," It is mustahabb to use the ablution from menstruation as an opportunity to keep you in the place of your father, part 1, p. 260, No. 332". 
is prohibited in and of itself explicitly. Secondly, it's better to mention all of the authentic evidences which the scholars of past have used in terms of the prohibition of shaking hands with strangers of the opposite gender. We must check the rulings because we know that eventually it boils down to the strength of the evidence. It is prohibited to touch a stranger of the opposite gender with sexual desire, and there is no flexibility in that regard. It is permissible to touch a stranger of the opposite gender whenever there is a genuine need. It is prohibited to touch strangers of the opposite gender without sexual desire but there is some flexibility to stretch this opinion from prohibition (haram) to dislike -

\section{CONCLUSION OF THE STUDY:}

The study concluded that our society cannot flourish without professional and healthy interactions between men and women. Pretending that such is possible simply does not make sense. Conversely, it is undeniable that there is a natural attraction between both genders, so how does one find the right balance between need and attraction? During the time of Prophet Muhammad (there did exist interactions between men \& women, and there are many Ayaat and Ahadith which depict such happenings (as we will discuss in this research). In our global society we have to interact with the opposite gender whether we live in a Muslim-majority country, or a Non-Muslim-majority country. Rather than just saying that men-women interactions are not permissible except when needed, the focus should be to provide guidelines and protocols to follow and abide by for when the time of 'need' arises. In this way, we can work on making every interaction professional and permissible in the sight of Allah. Our focus is also due to the fact that many scholars wrote about intermixing (اختلاط) 
previously, but very rarely did they weigh in on the principles of, and guidelines for interactions. It is permissible for a man/woman to look at each other's faces or any other part which isn't part of the 'awrah, provided there are no sexual desires (الثهوة) of any sort or temptation (خوف) الفتنة). It is prohibited to look at a stranger from the opposite gender with sexual desire or temptation according to all of the scholars.

\section{(C) (1)(}

